\title{
The Value and Realization of Incorporating the Long March Spirit into the Ideal and Belief Education of Colleges and Universities
}

\author{
Wei Dai \\ Century College \\ Beijing University of Posts and Telecommunications \\ Beijing, China 102101
}

\begin{abstract}
Long March spirit is a vivid manifestation of the lofty ideal and belief and ethos of the Chinese Communists. It is a strong mental power stimulated a generation and generation of Chinese people to continue to win. At present, the ideal and belief of college students is confronting with intensive impact of the confrontation among different ideologies and cultures and severe challenge brought by the social trend of diversified thoughts. With the life force and value of the times surpassing historical time and space, Long March spirit can be used as an important resource for the ideal and belief of college students in the new period. The ideal and belief education of college students should deeply explore the modern value of the Long March spirit and better incorporate the spirit into ideal and belief education of colleges and universities.
\end{abstract}

Keywords-new period; colleges and universities; Long March spirit; ideal and belief

\section{INTRODUCTION}

The great Long March 80 years ago makes the Long March spirit shining throughout the history, and the rich ideal and belief educational factors contained in the spirit are valuable resources for providing college students with ideal and belief education. Xi Jinping emphasized on the National Colleges and Universities Ideological and Political Conference, "It is necessary to educate and guide students to establish their belief and confidence in striving to realize lofty ideal of communism and the common ideal of socialism with Chinese characteristics." [1] He highly praised the great Long March spirit on the 80th annual general meeting for commemorating the victory of the Long March, "The great Long March spirit is to regard the fundamental interests of the national people and Chinese nation above all else, strengthen the ideal and belief of the revolution, firmly believe in that just cause will inevitably win, dare to overcome all difficulties and obstacles and even sacrifice in order to save the country and the people, keep on the principle of being independent, being practical and realistic and proceeding from actual conditions all the time, pay attention to the interests of the whole, strictly abide by disciplines and close the ranks as well as closely rely on the masses, never leave the masses for sake of safety, share weal and woe with the masses and work hard together with the masses." [2] It is the most vivid embodiment of the revolutionary spirit of the Chinese Communist Party and the people's army led by the Party, and it is the most concentrated demonstration of national character of the Chinese nation and the most profound interpretation of the patriotism oriented national spirit. With the life force and value of the times surpassing historical time and space, Long March spirit is a precious resource for the ideal and belief of college students in the new period. In providing students with ideal and belief education, colleges and universities should fully explore the time significance of Long March spirit and get the spirit fully incorporated into students' ideal and belief education in colleges and universities.

\section{SPECIFIC EMBODIMENT OF THE FIRM IDEAL AND BELIEF OF REVOLUTIONARY ANCESTORS IN THE LONG MARCH OF THE RED ARMY}

In October 1934, the Central Red Army suffered an incalculable loss from the failure of the fifth campaign against encirclement and suppression due to strategic mistakes made by $\mathrm{Bo} \mathrm{Gu}$ (the leader of the Central Committee of the Communist Party of China at that time) and $\mathrm{Li} \mathrm{De}$ (the military adviser dispatched from the Communist International). Under the extremely severe conditions, the Central Red Army had to leave the revolutionary base, implementing strategic transference, and thus started the great miracle in history of human beings Long March, in order to get rid of the insane encirclement and suppression of the army of Nationalist Party and survive. During the Long March, the Central Red Army overcame difficulties and obstacles, passed through 14 provinces, climbed over 18 huge mountains, went cross 24 great rivers, including snow-capped mountain and wet meadow. The whole journey is about 25000 miles. Although the natural environment is hard, it is much more severe under insane encirclement and suppression of the army of Nationalist Party. During the Long March, the Central Red Army captured more than 700 counties and carried out more than 380 battles with the army of Nationalist Party. More than 400 cadres at the battalion level were sacrificed. Their average age is even less than 30 years old. They all dare to sacrifice for realizing their great ideals. The Central Red 
Army carried forward the spirit of "not afraid of suffering and not afraid of death", fought bravely and eventually defeated hundreds of regiments of Nationalist Party. The 25,000 miles of long march of the Central Red Army created a far-reaching Long March spirit and concentrated the red gene of the spirit of Chinese nation. The enriched ideal and belief education factors contained in the Long March spirit is a shining light guiding college students in the new period to form a correct value concept and is formation of correct values for college students in the new era, and is valuable resource for providing them with ideal and belief education. Without the firm ideal and belief of the revolutionary ancestors at that time, there would be no the great Long March spirit. The firm ideal and belief of the revolutionary ancestors in the Long March are mainly manifested in the following aspects:

\section{A. They Always Treated the Ideal and Belief of Communism as the Foundation of Life}

The firm scientific ideal and belief are the powerful spiritual pillar and magic political weapon for Chinese Communists to win and succeed in the revolution, construction and reform. Xi Jinping pointed out, "In the history of our party for more than 90 years, countless Communists have not hesitated to sacrifice themselves just depending on this belief and for realizing this ideal." $[3]^{160}$ In his speech in 2013, he emphasized that "the revolutionary ideal is higher than the sky" $[3]^{23}$ made scientific orientation and highly evaluation on the revolutionary ideal and belief from the strategic level and long-term planning and fully affirmed the great role that the ideal and belief played in each period of the revolution, construction and reform. In his view, "firming the ideals and beliefs and sticking to the spiritual pursuit of Communists has always been the foundation for life of Communists." [3 $]^{159}$ Since the day of its founding, the Communist Party of China had written Marxism on its own banner and had treated the realization of socialism and communism as its struggling objectives. The Chinese Communists kept this great ideal in mind all the times and firmly believed that the revolutionary ideal was more important than heavens. In the course of the Long March, the Central Red Army always treated this ideal and belief as the foundation of its own life and finally built up the core and soul of Long March spirit. It might be hard for the Red Army to win finally without supporting of the firm ideal and belief as a support, because of the insane encirclement and suppression of the army of Nationalist Party in addition to the very severe national conditions on the Long March road. This is extremely rare in history of human beings. Among the 18 great mountains climbed over by the Red Army during the Long March, five of them were snowcapped all the year round; among the 24 rivers went across by the Red Army, they might confront with surviving disaster every time they went across a river; and among the warlord organizations in ten regions they broken through, they almost died every time they defeated the organization in one region. During the Long March, the Central Red Army marched 71 miles a day on average. It is almost unimaginable to maintain such a marching speed in the most severe environment on the earth. Today, the story is still admirable. Someone asked the old Red Army General Xie Zhenhua what on earth they relied on to overcome the long march? He said, "It's our belief in the revolution. People can't live without belief. When we climbed the snow-capped mountains and grassland, the reason why Red Army could survive was because we thought that this suffering was all for liberating and changing the destiny of the masses. We believed that we would finally win the war if we follow by the Communist Party to fight for peace of the masses. Without such a belief, it was impossible to complete the 25,000-mile long march. "Under strong supporting of the firm ideal and belief, the Central Red Army didn't stop forging valiantly ahead in confronting with insane encirclement and suppression of the army of Nationalist Party, even facing threat of death and even being driven to the last ditch for many times. This became a precious spiritual treasure for them to climb snow-capped mountains, pass grasslands and finally gained the Long March victory. In the process of realizing this lofty ideal and belief, countless martyrs sacrificed their lives to save the country and the masses. Many fighters believed that there was nothing to regret if they died for the revolution. "This ideal makes this Red Army different from any army in Chinese history."[4]

\section{B. They Created a Monument of Ideal and Belief by Sacrificing Themselves Without Regret}

It can be said that correct ideal and belief is a smelter creating souls and only those who have firm ideal and belief can be called having soul. If one does not have firm ideal and beliefs, he/she may lose the direction of life, do nothing, or even slip into the fallen abyss. The revolutionary ancestors who participated in the Long March firmly believed that saving the country and saving the people were the truth. They firmly believed that only Marxism can guide Chinese revolution. Only Chinese Communist Party can save China so that they steadfastly followed the steps of the Communist Party. In order to save the country and save the people and for the sake of their ideals and beliefs, they were willing to give up their originally comfortable life, left their families, went to suffer, sacrifice, withstand the most severe test in human history and created a monument of ideal and belief by using their lives and bloods.

The Long March is hard, and the bitterest thing is climbing the snow-capped mountains and going across grasslands. Almost every revolutionary ancestor experienced the Long March may describe the experience in a word "bitter" when they recall the experience of climbing the snow-capped mountains and going across grasslands. After many years, that feeling is still deep into the bone marrow. The white snow made people unable to open their eyes, not available to find a way out, but only slide on the ice, fell and then re-stand up for countless times. Coupled with lack of clothing and food, people were very exhausted. It was a great physical and psychological test and some people falling asleep in the snow might never wake up. The 92-year-old Zhang Shaoquan maintains still fresh in his memory that many Red Army soldiers from the South "wore a tattered garment of single layer", and their feet with blood blisters 
were still "wrapped with dry bark..." [5] The follow-up army did not need to look for road sign, but can find the advancement route along the dead bodies of their comrades, can find the way forward. This is what the veteran Red Army man once responsible for taking in comrades lagged behind describes to express how many soldiers sacrificed it was at that time. According to the statistics of the Liberation Army Daily, the First Front Red Army had lost about 6,000 soldiers from the almost 20,000 soldiers before going across grasslands to 13,000 soldiers after going out of grasslands. The Second Front Red Army had lost about 3,000 soldiers from the 16,000 soldiers before going across grasslands to 13,000 soldiers after going out of grasslands. The Fourth Front Red Second Army lost most seriously and lost almost 7,000 soldiers only in the third going across grassland. Before the end of the Long March, twelve soldiers died in Yakexia Mountain and their bodies were found even after 16 years. These silent lives marked the spiritual height of the tragic march. This is the highest red army tomb in the world, which has created the spirit of the Long March shining in the history and is a concentrated embodiment of the spirit of Chinese nation. There is no doubt that the Red Army's climbing of snow-capped mountains and grassland is the most tragic death march in human history and the most solid foundation for the formation and development of the Long March spirit.

When talking about the Long March, Mao Zedong said, "We acquired experiences after suffering from such a big setback and pains!"[6] Marx emphasized the role of practice. It was the practice of struggling in difficult environment that cultivated the revolutionary style of the officer and men of the Red Army, strengthened their ideal and belief, and honed their tenacity of will, and further formed the Long March spirit admirable for the future generations on this basis of these. Deng Xiaoping stressed, "Why can we struggle in the very difficult circumstances and overcome thousands of difficulties to achieve the victory of the revolution in the past?" It is because we have ideals, Marxist beliefs and communist beliefs. "[7] Therefore, it can be said that if there is no the firm ideal and belief, there will be no long march spirit in the annals of history.

\section{THE VALUE OF INCORPORATING LONG MARCH SPIRIT INTO IDEAL AND BELIEF EDUCATION FROM THE PERSPECTIVE OF CURRENT STUDENTS' IDEOLOGICAL CHARACTERISTICS}

Firm and correct ideal and belief is the foundation of an individual's life and stability and also a great spiritual pillar for a country, a nation and political party to survive and develop. In the past 40 years of reform and opening up, the mainstream of thought of college students in China has shown a good trend of being in positive, healthy and upward development. Xi Jinping emphasized, "In the historical new period of reform and opening up, the vast majority of young people have issued a strong voice of unity and rejuvenation of the Chinese nation, and for the prosperity and prosperity of the motherland to forge ahead and innovate."[8] Especially in the images of outstanding youth representatives," they fully embody the contemporary youth's lofty ambitions for serving the motherland, the vigorous spirit, the personality to constantly strive to become stronger and the dedication ideological realm and also fully reflect the youth's firm belief in socialism with Chinese characteristics and confidence to achieve great rejuvenation of Chinese nation" [8]. However, it should be noted that in the context of multi-polarization and economic globalization in the world today, multiple cultures has collided freely and easily, interest differences have increased significantly, and social contradictions have become increasingly prominent. Some of the "generation after 1995" of college students' ideal and belief have begun to waver. They begin feeling confused and embarrassing in making choice of value and objective of life.

\section{A. They Have Weak Ideal and Belief and Their Beliefs in Marxism and Communism Are Shaken}

College students are in a critical period of their life development. During this period, although they are physiologically close to the peak of life, they are still in a psychologically transitional stage toward becoming fully mature. Due to psychological immaturity and lack of social practice, some students are extremely susceptible to the influence of external environment and trend of thoughts and further appear the characteristics of weak and confused ideal and belief. Some students show envy in face of the strong economic and scientific strength of Western capitalist developed countries, agree with the so-called "end of history" comment in the West and doubt about the "twoinevitable" science ideology of Marxism namely the thought that capitalism is inevitably going to die and socialism is inevitably going to win, thus appearing the Marxist belief crisis. In detail, it is manifested in their vague understanding of the belief of Marxism and ideal of Communism, lacking of confidence in the "four self-confidences", and further having insufficient determination to struggle for realizing communism ideal. Some students even think that communism is just a fantasy, a mirage that is impossible to reach and can never be realized. Other students believe that even if communism can be realized one day, it is a matter of more than a dozen generations, dozens of generations, and even longer in the future and is illusory. They have a very negative attitude towards the realization of communism. Some students even think that ideals are for excellent students. They are just ordinary college students. They have no requirement for joining the party; hence there is no need to talk about ideals and beliefs. They believe that it'd be better to enjoy the beautiful real life instead of struggling for such an insubstantial ideal and belief. This perfunctory thinking reflects that some students lack firm belief in Marxism and communism. This kind of performance is worthy of consideration and thinking.

\section{B. They Have Not That Strong Social Recognition Ability and Their Ideal and Belief Obviously Tend to Be Low- level and Utilitarian}

As required by the Party and the country, college student should be bold in pursuing truth, strive for the common ideal of socialism with Chinese characteristics, learn to revitalize China, and create a valuable life while dedicating their youth. 
At present, China's society has entered a new era, but it is still in a period of social transformation. Various ideas and cultures affect each other and collide with each other. Those thoughts will inevitably have an impact on college students. Western individualism, liberalism, hedonism and other concepts of value have obvious influence on current college students. Their values are no longer unitary but diversified. In 1950s 1960s, college students regarded the prosperity of China, revitalization of Chinese nation and the happiness of the people as the greatest happiness in life and treated the success in career, realization of social values and contribution to the country as the greatest success of life, while contemporary college students have less social contact and less social recognition. In addition to being affected by bad factors, they begin paying more attention to individual ideals than social ideals and more to short-term ideal than long-term ideal. Their ideals tend to be utilitarian and realistic and other low level. A small number of college students are greatly affected by pragmatism, hedonism and money worship. "Our inner world has become 'old' from the childhood to the 'old'. Under the influence of parents and society, we have heard the rules of the adult world too early. We not only know about and agree with the mainstream ideas and concept of values in contemporary Chinese society, but also have more realistic value pursuit and choice. Market consumption concepts are intensified and utilitarianism and fame and fortune are over-enhanced. "[12] This excessively utilitarian individual ideal will not only affect the realization of personal happiness, but also affect the realization of the "two hundred years" of struggling objectives and Chinese dream.

\section{WAY OF INCORPORATING THE LONG MARCH SPIRIT} INTO THE IDEAL AND BELIEF EDUCATION IN COLLEGES AND

\section{UNIVERSITIES}

The Party and the country have always attached great importance to the education of ideals and beliefs of college students. In the "Opinions on Further Strengthening and Improving the Ideological and Political Work of Colleges and Universities under the New Situation" issued by the Central Committee of the Communist Party of China and the State Council in February 2017, it was re-emphasized that the strengthening and improvement of ideological and political education in colleges and universities under the new situation should focus on the education of ideal and belief and put the education of ideal and belief in the first place. In the report of the 19th National Congress of the Communist Party of China, General Secretary Xi Jinping pointed out that "it is necessary to inherit the revolutionary culture" and promoting the integration of the Long March spirit and the ideal and belief education of college students is right the process of cultivating college students to inherit the revolutionary culture.

\section{A. Getting Long March Spirit Combined with the Construction of Campus Culture and Enhancing the Ideal and Belief Awareness of College Students}

The campus culture is closely related to the daily life and study of college students. It is closer to the students. So, it is available to get Long March spirit and other red culture incorporated into the campus culture with clear theme, specific content and rich forms, hold Long March spirit themed class meetings, speech contests, essays soliciting and other activities, adopt the popular and interesting way to attract students' interest in learning and provide such ideal and belief education in subtle ways, such as playing Long March images when students are dining, propagandizing the heroic deeds of the Red Army during the Long March on the campus network and carrying out the re-walking on the Long March road and other activities, so that students can understand the connotation and essence of the Long March spirit, understand the hardships and sacrifices of the older generation of revolutionaries and understand the hard-earned peaceful environment today under a strong campus culture, and hence cherish the current study and life, strengthen the correct ideal and belief and follow up the older generation's way. Carrying forward Long March spirit and other red culture is the core of the ideal and belief education in colleges and universities and also the key for college students to cultivate and put into practice the concept of core values of socialism. Learning and promoting the Long March spirit can also help college students to strengthen their political awareness, firm their political stance and help students form correct world outlook, outlook on life and values and lay a good foundation for their life. Long March spirit is the immortal volitional quality created by countless sacrifices of the revolutionary martyrs. It reflects that the Red Army of the Chinese Workers and Peasants will not forget their responsibility and mission and don't afraid of sacrificing and going forward regardless of the harsh environment. Comparing the extreme environment of the revolutionary ancestors of the Red Army faced during the Long March with the spacious, quiet and harmonious classroom environment of college students today, students can understand that material wealth is only external and a soldier without firm ideals and beliefs may don't know what's his objective even though he has tanks, cannons and machine guns. Therefore, a firm ideal and belief can help college students to abandon the concept of hedonism and achieve the realm of "Only after knowing the realm to be achieved can one fix his/her ambition; only after fixing the ambition can one do things with calm mind; only after calming down can one consider carefully and only after considering carefully can one achieve the expected realm" as stated in "The Great Learning".

\section{B. Getting Long March Spirit Incorporated into the Ideal and Belief Education of College Students and Enriching the Content and Form of Teaching}

Although the Red Army's Long March has passed for more than 80 years, the spirit of sacrificing, undertaking of saving the country and the masses and the firm ideal and belief of communism demonstrated by the revolutionary ancestors and the Chinese Communists in the long march provide very rich red culture resources for ideal and belief education college students in the new era and become a valuable spiritual wealth to enhance students' ideological and moral qualities and to strengthen their ideal and belief. the rich and vivid and typical deeds of the revolutionary 
ancestors and the Chinese Communists confronted with in the course of the Long March of the Red Army such as their fearless sacrificing, their firm belief in communism and their persistent pursuit of truth form a precious and irreplaceable textbook for school to provide college students with ideal and belief education and can complement and enrich the content and effectiveness of the education of ideal and belief. In teaching, it is available to adopt projection, video, audio, photos and other forms or let students perform group performances to restore the scenes at that time, so that students have a more intuitive and profound understanding and experience of the firm ideal and belief of the revolutionary ancestors in the course of the Long March. At the same time, it is available to hold Long March spirit themed speech, essay contest and other activities in colleges and universities every year to continuously enrich the content and form of ideal and belief education. It is possible to closely combine with the social reality and student's ideological reality, detail the abstract theory, and get it close to the students' reality. It is also suggested to organize students to re-walk on the long march road by virtue of the summer social practice to experience the Long March spirit practically and let students affirm their ideal and belief.

\section{Giving Full Play to the Leading Role of the Long March Spirit in the Thinking of College Students and Establishing a Firm Ideal and Belief}

In the report of the 19th National Congress of the Communist Party of China, General Secretary Xi Jinping pointed out that "it is necessary to inherit the revolutionary culture" and the process of incorporating the Long March spirit into the ideal and belief education of college students is also the process of cultivating college students to inherit the revolutionary culture. College students' concept of values is gradually forming up and is easy to be interfered by the outside world, showing certain volatility and plasticity. This also provides a sally port for incorporating the Long March spirit into their value concept. It is possible to find the demand of college students by designing situations suitable for college students. The key to the success of the incorporation of Long March spirit is to resonate with the educated, so that this spirit can penetrate into the heart of students and truly affect students. Therefore, in providing college students with ideal and belief education, it is necessary to give full play to the leading role of the Long March spirit in the thinking of college students and encourage college students to actively participate in the colorful activities on learning and promoting the Long March spirit. College students' ideal and belief education is the core of ideological and political education in colleges and universities. The red resources such as the Long March spirit are the ceaseless source of ideal and belief education in colleges and universities in the new era.

\section{CONCLUSION}

In order to incorporate the red resources represented by the Long March spirit into the ideal and belief education of colleges and universities, it is necessary to take the cultivation and practice of the core value concept of socialism as the starting point and the foothold, guide the students to deeply understand the Long March spirit, inherit the red genes, and constantly explore the incorporation of red resources into the new vision and new height of ideal and belief education for college students so as to help college students to strengthen their ideal and belief and enhance the pertinence and effectiveness of ideal and belief education in colleges and universities.

\section{REFERENCES}

[1] Xi Jinping's emphasis on the National Conference on Ideological and Political Work in Colleges and Universities: putting ideological and political work throughout the whole process of education and teaching and creating a new situation in the development of higher education in China [N]. People's Daily, Dec.9, 2016 (1). (in Chinese)

[2] $\mathrm{Xi}$ Jinping. Speech at the 80th annual general meeting for commemorating the victory of the Long March [N]. People's Daily, Oct.22, 2016. (in Chinese)

[3] Propaganda Department of the CPC Central Committee. General Secretary Xi Jinping's series of important speeches (textbook) [M] Beijing: Learning Press, 2014. (in Chinese)

[4] Zhang Xiao. A brief analysis of the Ssignificance of Communism belief to the Long March spirit[J]. Heritage. 2013 (7): 50-51. (in Chinese)

[5] Liu Yonghua, Wu Jie, Fan Yongqiang. "The most tragic death march": full record of the Red Army's climbing snow-capped mountains and going across grasslands [EB/OL] http://news.xinhuanet.com/mrdx/2006-09/27/content 5382.htm: Xinhuanet, Sep.27, 2006. (in Chinese)

[6] Mao Zedong. Speech at the Enlarged Central Working Conference [M]. Beijing: People's Publishing House, 1978. (in Chinese)

[7] Selected Works of Deng Xiaoping (Vol. 3) [M]. Beijing: People's Publishing House, 1993: 110. (in Chinese)

[8] $\mathrm{Xi}$ Jinping. Speech at a meeting with outstanding youth representatives from all fields [EB/OL]. www.gov.cn. 2013-05-05. (in Chines) 